\title{
Atrial fibrillation post cardiac bypass surgery
}

Ashraf Mostafa, Mohamed A. EL-Haddad, Maithili Shenoy, Tushar Tuliani

Department of Internal Medicine, Wayne State University School of Medicine, Detroit, MI, USA

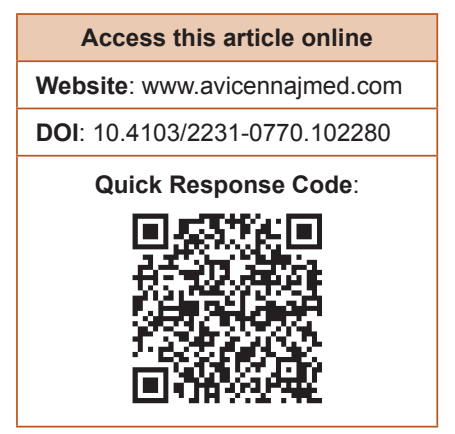

\section{DEFINITION}

Atrial fibrillation $(\mathrm{AF})$ is a supraventricular tachyarrhythmia characterized by uncoordinated atrial activation with subsequent deterioration of mechanical function. Postoperative atrial fibrillation (POAF) is common after both cardiothoracic and noncardiothoracic surgery. AF has been reported in up to $5-40 \%$ of patients in the early postoperative period following coronary artery bypass graft $(\mathrm{CABG}),{ }^{[1-3]}$ in $37-50 \%$ after valve surgery, ${ }^{[4]} 64 \%$ undergoing mitral valve replacement plus CABG, $49 \%$ undergoing aortic valve replacement (AVR) plus CABG and in $12 \%$ after cardiac transplantation. ${ }^{[5,6]}$ POAF after cardiac surgery tends to occur within 2-4 days after the procedure with a peak incidence on postoperative day $2 \cdot{ }^{[1]}$ In a study by Aranki et al. on CABG patients, $70 \%$ and $94 \%$ patients developed POAF before the end of postoperative day 4 and 6 , respectively. ${ }^{[7]}$

AF worsens a patient's hemodynamic status and increases the risk of congestive heart failure (CHF), embolic events and longer ICU stays. AF may also necessitate the use of atrioventricular nodal blocking and antiarrhythmics, which may increase the need for cardiac pacing. Stroke is a major complication seen in $2 \%$ of CABG patients, $37 \%$ of whom had preceding AF. Apart from a higher risk of stroke (OR 2.02), POAF after CABG was associated with greater in-hospital mortality (OR 1.7) and worse survival (74\% vs. 87\%) at long-term follow-up (4 - 5 years). ${ }^{[8]}$ After controlling for a comprehensive array of risk factors associated with postcardiac surgery adverse outcomes, risk of long-term mortality in patients who developed new-onset POAF was $29 \%$ higher, for patients who underwent CABG. ${ }^{[9]}$

The impact of POAF on hospital resources is substantial and was estimated to lengthen hospital stay by 4.9 days, with an extra cost of $\$ 10,000$ to $\$ 11,500$ in hospital stay costs in the U.S. ${ }^{[7]}$ Knowing that there are at least 640,000 open heart surgeries/ year in the U.S. according to the American Heart Association statistics in 2004 and assuming an incidence of $30 \%$ of POAF, the extra cost related to this postoperative complication could be estimated at a staggering $\$ 2$ billion/year. ${ }^{[10]}$

\section{PATHOPHYSIOLOGICAL MECHANISMS}

The precise mechanism of post-CABG AF is still being investigated. The following pathophysiological factors play an important role: atrial factors (age-related structural changes such as atrial dilatation, hypertrophy, fibrosis and senile amyloidosis), postoperative inflammation (making the myocardium a tissue mosaic of differing refractory periods and conduction velocities susceptible to aberrant electrical activity, conduction and re-entry - the 'anisotropic' atrium, ${ }^{[11,12]}$ pericarditis, ${ }^{[13]}$ electrical remodeling (shortening of the effective refractory period) ${ }^{[14-16]}$ autonomic imbalance (over activation of the sympathetic nervous system in response to stress, increased vagal tone,${ }^{[17-20]}$ atrial incision, perioperative ischemia, ${ }^{[21]}$ alterations in atrial oxidative

Address for correspondence: Dr. Mohamed EL-Haddad, Resident, Detroit Receiving Hospital, Wayne State University-Detroit Medical Center, USA E-mail: melhadda@med.wayne.edu 
stress ${ }^{[1,22]}$ increased expression of the gap-junctional protein connexin $40,{ }^{[23]}$ inflammatory mediators and leucocytosis after extracorporeal circulation. ${ }^{[24,25]}$ Some theories proposed for AF in general are 'Theory of Multiple Wavelets' ${ }^{[5,26-28]}$ and 'Theory of Unifocal/ Multifocal Impulse Formation and Re-entry. ${ }^{[29-31]}$ However, it is unclear if these theories hold good for post-CABG AF.

\section{RISK FACTORS}

Many risk factors have been investigated in the past; however, we will focus on those found consistently in multivariate analyses in major trials.

\section{Preoperative}

Advanced age; ${ }^{[7,32,33]}$ male gender; genetic predisposition assessed by the interleukin- 6 promoter gene variant, ${ }^{[34]}$ history of CHF or AF; chronic obstructive pulmonary disease, chronic renal insufficiency, diabetes mellitus, rheumatic heart disease, ${ }^{[2,5,33,35]}$ previous cardiac surgery, metabolic syndrome, obesity, ${ }^{[36-38]}$ absence or withdrawal of beta-blocker or ACE inhibitor treatment, high pre-op Brain Natriuretic Peptide, ${ }^{[39]}$ severe proximal right coronary artery stenosis, ${ }^{[40]}$ mitral valve disease, ${ }^{[41]}$ increased left atrial size, ${ }^{[42]}$ decreased left ventricular ejection fraction, left atrial volume index $\geq 75$ $\mathrm{mL} / \mathrm{m},{ }^{[43]}$ preoperative increase in $\mathrm{P}$ wave duration on surface $(>116 \mathrm{~ms})$ or on signal averaged $(>140 \mathrm{~ms}) \mathrm{EKG}^{[44-46]}$ and blood transfusion before surgery. ${ }^{[44-47]}$

Age is consistently the independent factor most strongly associated with POAF. For every decade there is a $75 \%$ increase in the odds of developing POAF and based on age alone, anyone older than 70 years is considered to be at high risk for developing $\mathrm{AF}^{[2]}$ Age-associated changes in the atria such as dilatation, muscle atrophy, and decreased conduction may explain the strong association.

Concomitant valvular heart disease is also associated with postoperative atrial tachyarrhythmias. It is unclear whether this is because of the additional complexity of the required surgical procedure or the valvular disease itself. Neither the degree of ischemia nor the extent of coronary artery disease is a consistent predictor of postoperative atrial tachyarrhythmias. ${ }^{[3,48,49]}$

When beta-blocker was continued or started postoperatively, POAF risk was significantly reduced by $51-68 \% .{ }^{[2]}$ The use of adrenergic drugs is an independent risk factor for AF post-CABG. ${ }^{[50]}$

\section{Intraoperative}

Prolonged mechanical ventilation, atrial ischemia, hypokalemia, ${ }^{[51]}$ hypomagnesemia. ${ }^{[52]}$ There is conflicting data whether increased aortic cross-clamp and cardiopulmonary bypass time increase POAF. ${ }^{[7]}$

\section{Postoperative}

A substudy of the Atrial Fibrillation Suppression Trial II (AFIST) showed that patients who developed postoperative AF received $1.3 \mathrm{~L}$ more fluid than those without postoperative AF over 5 postoperative days. ${ }^{[53]} \mathrm{Net}$ fluid balance on postoperative day 2 was an independent predictor of post-CTS AF among amiodarone-naive patients (OR 6.4; 95\% CI 1.4 to 29.1) which is noteworthy since most post-CTS AF occurs on this day. ${ }^{[54]}$

Characteristics that have not been identified consistently as independent risk factors include hypertension, left ventricular dysfunction, angina pectoris, and noncardiac illnesses.

\section{PREVENTION}

\section{Beta-blocker}

Since the autonomic nervous system plays a major role in the pathophysiology of post-CABG AF, beta blockers have been widely studied in its prevention. In one study beta-blockers had the greatest magnitude of effect across 28 trials (4,074 patients) with an odds ratio (OR) of $0.35,95 \%$ CI 0.26-0.49. ${ }^{[55]}$ In another meta-analysis of 24 trials limited to patients with ejection fraction $>30 \%$ undergoing CABG, prophylactic beta-blockers were associated with protection against supraventricular tachycardia with an OR of 0.28 , 95\%CI 0.21-0.36. ${ }^{[56]}$

\section{Sotalol}

In a meta-analysis of 14 trials including 2,583 patients that compared beta-blocker or placebo, sotalol was found to be more effective in reducing POAF than beta-blocker or placebo. Therefore, it seems to offer significant additional protection over standard beta-blockers. ${ }^{[57]}$

\section{Amiodarone}

In a randomized trial including 124 patients undergoing a complex cardiac surgery, amiodarone administered orally at least 1 week preoperatively significantly reduced the incidence of POAF, from $53 \%$ in the placebo group to $25 \%$ in the treated group $(P=0.003)$. In the Amiodarone Reduction in Coronary Heart $(\mathrm{ARCH})$ trial, postoperative intravenous administration of amiodarone was associated with a lower incidence of POAF (35\%) compared with the placebo arm $(47 \%)(P=0.01) \cdot{ }^{[58]}$

\section{Atrial pacing}

Prophylactic pacing has been investigated in a number of trials. Meta-analyses of these clinical trials have consistently 
shown that single- or dual-site atrial pacing significantly reduces the risk of new-onset POAF. ${ }^{[5,60]}$ In a randomized trial, biatrial overdrive pacing in patients undergoing $C A B G$ was shown to be more effective in preventing POAF than single-site atrial pacing $(12.5 \%$ vs. $36 \%) \cdot{ }^{[61]}$ However, this trial included a small number of patients and had significant limitations. Major adverse effect is potential proarrhythmic effect.

\section{Calcium channel blockers}

A recent meta-analysis showed that calcium-channel blockers reduce supra-ventricular tachyarrhythmia risk (OR 0.62; 95\% CI 0.41-0.93). ${ }^{[62]}$ However, in some studies, the perioperative use of these drugs was associated with an increased incidence of AV block and low output syndrome, due to their negative chronotropic and inotropic effect. In patients undergoing $C A B G$, diltiazem reduced post-CABG $\mathrm{AF}$ incidence by $50-74 \%$ compared with placebo. ${ }^{[63]}$

\section{Magnesium}

A meta-analysis concluded that magnesium administration was effective for reducing POAF with a similar efficacy to common antiarrhythmic drugs. ${ }^{[64]}$ Meta-analyses have shown magnesium to reduce POAF risk by $23-36 \% .{ }^{[64,65]}$ However, the studies included in these analyses included a small number of patients, and the design varied among the different studies, thus limiting the interpretation of the results.

Statins- The prospective randomized study Atorvastatin for Reduction of MYocardial Dysrhythmia After cardiac surgery (ARMYDA-3) has demonstrated that treatment with Atorvastatin $40 \mathrm{mg} /$ day started 7 days before elective cardiac surgery under cardiopulmonary bypass and continued in the postoperative period significantly reduces the occurrence of POAF by $61 \%{ }^{[66]}$ Statins have been shown to reduce inflammation in patients with coronary artery disease; and thus the theoretical benefit to decrease postoperative inflammation as a potential cause of POAF. When the theory examined was found to be useful in the prevention of POAF.

\section{$\mathrm{N}-3$ polyunsaturated fatty acids}

In a randomized controlled trial of 160 patients undergoing elective CABG, PUFAs supplementation significantly reduced the incidence of POAF by $65 \%$ versus control, an effect similar to that obtained with beta-blockers, sotalol, or amiodarone (OR 0.35; 95\% CI 0.16-0.76). ${ }^{[67]}$ The modulation of cardiac connexin was probably the contributing mechanism to the antiarrhythmic effects of fish oil supplementation. Furthermore, in the general population, consumption of fish, inducing high plasma PUFA concentration, has been associated with a lower incidence of AF in a 12-year follow-up study. ${ }^{[68]}$

\section{Anti-inflammatory agents}

In a randomised controlled trial the authors concluded that nonsteroidal anti-inflammatory medications are effective in significantly reducing the incidence of AF after CABG. However, the risk versus benefit ratio of such prophylactic strategy remains uncertain, given their nephrotoxicity. ${ }^{[69]}$ In another multicenter trial hydrocortisone proved beneficial in reducing the incidence of POAF in the first 84 hours. ${ }^{[70]}$

\section{TREATMENT}

Before initiating the treatment of AF, underlying medical comorbidities like electrolyte imbalance, hypoxia, COPD should be treated. ${ }^{[1]} \mathrm{AF}$ has been associated with physiological stress, drugs, pulmonary embolism, chronic lung disease, hyperthyroidism, caffeine, infectious processes, and various metabolic disturbances. AF has also been linked with obesity, and this phenomenon seems to be mediated by left atrial dilation

The treatment of post-CABG AF includes use of drugs and electrical cardioversion. Drugs can target to achieve rate control or rhythm control [Table 1]. According to a study

\begin{tabular}{|c|c|c|c|}
\hline Drugs & Adult dosage & Advantages & Side effects \\
\hline Esmolol & $500 \mu \mathrm{g} / \mathrm{kg}$ over I $\mathrm{min}$ then $0.05-0.2 \mathrm{mg} / \mathrm{kg} / \mathrm{min}$ & $\begin{array}{l}\text { Short-acting effect and short } \\
\text { duration }\end{array}$ & $\begin{array}{l}\text { Might worsen congestive heart failure; can cause } \\
\text { bronchospasm, hypotension; } A V B\end{array}$ \\
\hline Atenolol & $\begin{array}{l}\text { I-5 } \mathrm{mg} \text { IV over } 5 \mathrm{~min} \text { repeat after } 10 \mathrm{~min} \text { then } \\
50-100 \mathrm{mg} \text { b.i.d. PO }\end{array}$ & Rapid onset of rate control (IV) & \\
\hline Metoprolol & I-5 mg IV over $2 \mathrm{~min}$ then $50-100 \mathrm{mg}$ b.i.d. PO & Rapid onset of rate control (IV) & \\
\hline Digoxin & $0.25-1.0 \mathrm{mg}$ IV then $0.125-0.5 \mathrm{mg} /$ day IV/PO & Can be used in heart failure & Nausea, AVB moderate effect in POAF \\
\hline Verapamil & $\begin{array}{l}2.5-10 \mathrm{mg} \text { IV over } 2 \mathrm{~min} \text { then } 80-120 \mathrm{mg} / \text { day } \\
\text { b.i.d. PO }\end{array}$ & Short-acting effect & Might worsen congestive heart failure, AVB \\
\hline Amiodarone & $\begin{array}{l}2.5-5 \mathrm{mg} / \mathrm{kg} \mathrm{IV} \text { over } 20 \mathrm{~min} \text { then } 15 \mathrm{mg} / \mathrm{kg} \text { or } \\
1.2 \mathrm{~g} \text { over } 24 \mathrm{~h}\end{array}$ & $\begin{array}{l}\text { Can be used in patients with } \\
\text { severe LV dysfunction }\end{array}$ & $\begin{array}{l}\text { Thyroid and hepatic dysfunction, torsades de pointes, } \\
\text { pulmonary fibrosis, photosensitivity, bradycardia }\end{array}$ \\
\hline Procainamide & $10-15 \mathrm{mg} / \mathrm{kg}$ IV up to $50 \mathrm{mg} / \mathrm{min}$ & $\begin{array}{l}\text { Therapeutic levels quickly } \\
\text { achieved }\end{array}$ & $\begin{array}{l}\text { Hypotension, fever, accumulates in renal failure, can } \\
\text { worsen heart failure, requires drug level monitoring }\end{array}$ \\
\hline Ibutilide & $\begin{array}{l}\text { I } \mathrm{mg} I V \text { over } 10 \mathrm{~min} \text {, can repeat after } 10 \mathrm{~min} \\
\text { if no effect }\end{array}$ & Easy to use & $\begin{array}{l}\text { Torsades de pointes more frequent than amiodarone } \\
\text { and procainamide }\end{array}$ \\
\hline
\end{tabular}


conducted to study rate control versus rhythm control it was found that the latter is more beneficial because of a decreased time to cardioversion, prolonged maintenance of sinus rhythm, and decreased length of overall hospital stay. ${ }^{[72]}$

Short acting beta-blockers are the drug of choice, ${ }^{[71]}$ especially in patients with ischemic heart disease. They should be used with care in patients with asthma, COPD, congestive cardiac failure and AV conduction block, in whom they are relatively contraindicated. Among calcium channel blockers, verapamil and diltiazem can be used. Digoxin is less effective when adrenergic tone is high but might be used in patients with congestive heart failure. ${ }^{[73]}$ Amiodarone can also be used and is also known to improve hemodynamic status when used intravenously. ${ }^{[71,74]}$ the risks and benefits of this treatment option, including the conversion rates.

Electrical Cardioversion- Indications for performing electrical cardioversion in patients with post-CABG AF are hemodynamic instability, myocardial ischemia, acute pump failure and elective restoration of normal sinus rhythm after a failed pharmacological attempt. Cardioversion can be associated with thromboembolism if POAF is present for more than 48 hours. The guidelines for anticoagulation in post surgical patients are not clear. ${ }^{[71]}$

Thromboembolism prevention: AF after CABG poses an increased risk of cerebrovascular accidents in the form of stroke; ${ }^{[75,76]}$ however, using anticoagulants in the post operative period can lead to increased risk of bleeding and cardiac tamponade. ${ }^{[77]}$ The risks might far outweigh the benefits especially in patients with advanced age, previous history of bleeding and uncontrolled hypertension. ${ }^{[61]}$ Anticoagulants can be used for prolonged and/or frequent episodes of $\mathrm{AF}$ and is recommended by the American College of Chest Physicians in patients with history of stroke and transient ischemic attacks (30 days after the return of sinus rhythm). ${ }^{[78]}$ Anticoagulation should be considered in patients 75 years or older and patients with risk factors for stroke, while antiplatelet agents may prove useful in younger patients, subgroups in whom anticoagulation is contraindicated, and in patients with low risk for stroke. ${ }^{[79]}$

\section{CONCLUSIONS AND RECOMMENDATIONS}

POAF is a burden to our health care system and increases ICU stay. We do have multiple modalities which range from the conservative medical approach to invasive biatrial pacing, so it would be worthwhile to be able to predict the occurrence of POAF. Many recent studies have tried to find predictors of POAF. ${ }^{[80,81]}$ Developing a practical and simple
AF score that can predict POAF is in order, and further research is required as to how to interpret these criteria and use them to utilize the available prevention and treatment modalities.

\section{REFERENCES}

1. Maisel WH, Rawn JD, Stevenson WG. Atrial fibrillation after cardiac surgery. Ann Intern Med 2001;135:1061-73.

2. Mathew JP, Fontes ML, Tudor IC, Ramsay J, Duke P, Mazer CD, et al. A multicenter risk index for atrial fibrillation after cardiac surgery. JAMA 2004;291:1720-9.

3. Villareal RP, Hariharan R, Liu BC, Kar B, Lee VV, Elayda M, et al. Postoperative atrial fibrillation and mortality after coronary artery bypass surgery. J Am Coll Cardiol 2004;43:742-8.

4. Asher CR, Miller DP, Grimm RA, Cosgrove DM 3rd, Chung MK. Analysis of risk factors for development of atrial fibrillation early after cardiac valvular surgery. Am J Cardiol 1998;82:892-5.

5. Creswell LL, Schuessler RB, Rosenbloom M, Cox JL. Hazards of postoperative atrial arrhythmias. Ann Thorac Surg 1993;56:539-49.

6. Pavri BB, O'Nunain SS, Newell JB, Ruskin JN, William G. Prevalence and prognostic significance of atrial arrhythmias after orthotopic cardiac transplantation. J Am Coll Cardiol 1995;25:1673-80.

7. Aranki SF, Shaw DP, Adams DH, Rizzo RJ, Couper GS, Vander Vliet M, et al. Predictors of atrial fibrillation after coronary artery surgery. current trends and impact on hospital resources. Circulation 1996;94:390-7.

8. Blomstrom Lundqvist C. In: Raviele A, editor. Post CABG atrial fibrillation: What are the incidence, predictors, treatment, and longterm outcome?. Venice, Italy: Springer; 2005.

9. Filardo G, Hamilton C, Hebeler RFJr, Hamman B, Grayburn P. New-onset postoperative atrial fibrillation after isolated coronary artery bypass graft surgery and long-term survival. Circ Cardiovasc Qual Outcomes 2009;2:164-9.

10. American heart association heart disease and stroke statistics- update at-A-glance. Circulation. 2007; 115(5):e69-171.

11. Ishii Y, Schuessler RB, Gaynor SL, Yamada K, Fu AS, Boineau JP, et al. Inflammation of atrium after cardiac surgery is associated with inhomogeneity of atrial conduction and atrial fibrillation. Circulation 2005; 111:2881-8.

12. Tselentakis EV, Woodford E, Chandy J, Gaudette GR, Saltman AE. Inflammation effects on the electrical properties of atrial tissue and inducibility of postoperative atrial fibrillation. J Surg Res 2006;135:6875.

13. Willems S, Weiss C, Meinertz T. Tachyarrhythmias following coronary artery bypass graft surgery: Epidemiology, mechanisms, and current therapeutic strategies. Thorac Cardiovasc Surg 1997;45:232-7.

14. Zipes DP. Electrophysiological remodeling of the heart owing to rate. Circulation 1997;95:1745-8.

15. Van Wagoner DR, Pond AL, Lamorgese M, Rossie SS, McCarthy PM, Nerbonne JM. Atrial L-type Ca2 + currents and human atrial fibrillation. Circ Res 1999;85:428-36.

16. Nattel S. Ionic determinants of atrial fibrillation and $\mathrm{Ca} 2+$ channel abnormalities: Cause, consequence, or innocent bystander? Circ Res 1999;85:473-6.

17. Schauerte P, Scherlag BJ, Patterson E, Scherlag MA, Matsudaria K, Nakagawa $\mathrm{H}$, et al. Focal atrial fibrillation: Experimental evidence for a pathophysiologic role of the autonomic nervous system. J Cardiovasc Electrophysiol 2001;12:592-9.

18. Bettoni M, Zimmermann M. Autonomic tone variations before the onset of paroxysmal atrial fibrillation. Circulation 2002;105:2753-9.

19. Zimmermann M, Kalusche D. Fluctuation in autonomic tone is a major determinant of sustained atrial arrhythmias in patients with focal ectopy originating from the pulmonary veins. J Cardiovasc 
Electrophysiol 2001;12:285-91.

20. Dimmer C, Tavernier R, Gjorgov N, Van Nooten G, Clement DL, Jordaens L. Variations of autonomic tone preceding onset of atrial fibrillation after coronary artery bypass grafting. Am J Cardiol 1998;82:22-5.

21. Kanoupakis EM, Manios EG, Mavrakis HE, Kaleboubas MD, Parthenakis $\mathrm{FI}$, Vardas PE. Relation of autonomic modulation to recurrence of atrial fibrillation following cardioversion. Am J Cardiol 2000;86:954-8.

22. Carnes CA, Chung MK, Nakayama T, Nakayama H, Baliga RS, Piao S, et al. Ascorbate attenuates atrial pacing-induced peroxynitrite formation and electrical remodeling and decreases the incidence of postoperative atrial fibrillation. Circ Res 2001;89:E32-8.

23. Dupont E, Ko Y, Rothery S, Coppen SR, Baghai M, Haw M, et al. The gap-junctional protein connexin40 is elevated in patients susceptible to postoperative atrial fibrillation. Circulation 2001;103:842-9.

24. Abdelhadi RH, Gurm HS, Van Wagoner DR, Chung MK. Relation of an exaggerated rise in white blood cells after coronary bypass or cardiac valve surgery to development of atrial fibrillation postoperatively. Am J Cardiol 2004;93:1176-8.

25. Lamm G, Auer J, Weber T, Berent R, Ng C, Eber B. Postoperative white blood cell count predicts atrial fibrillation after cardiac surgery. $\mathrm{J}$ Cardiothorac Vasc Anesth 2006;20:51-6.

26. Moe GK, Abildskov JA. Observations on the ventricular dysrhythmia associated with atrial fibrillation in the dog heart. Circ Res 1964;14:44760.

27. Moe GK, Abildskov JA. Atrial fibrillation as a self-sustaining arrhythmia independent of focal discharge. Am Heart J 1959;58:59-70.

28. Cox JL. A perspective of postoperative atrial fibrillation in cardiac operations. Ann Thorac Surg 1993;56:405-9.

29. Jais P, Haissaguerre M, Shah DC, Chouairi S, Gencel L, Hocini M, et al. A focal source of atrial fibrillation treated by discrete radiofrequency ablation. Circulation 1997;95:572-6.

30. Haissaguerre M, Jais P, Shah DC, Takahashi A, Hocini M, Quiniou G, et al. Spontaneous initiation of atrial fibrillation by ectopic beats originating in the pulmonary veins. $\mathrm{N}$ Engl J Med 1998;339:659-66.

31. Chen SA, Tai CT, Yu WC, Chen YJ, Tsai CF, Hsieh MH, et al. Right atrial focal atrial fibrillation: Electrophysiologic characteristics and radiofrequency catheter ablation. J Cardiovasc Electrophysiol 1999;10:328-35.

32. Almassi GH, Schowalter T, Nicolosi AC, Aggarwal A, Moritz TE, Henderson WG, et al. Atrial fibrillation after cardiac surgery: A major morbid event? Ann Surg 1997;226:501-11; discussion 511-3.

33. Mathew JP, Parks R, Savino JS, Friedman AS, Koch C, Mangano DT, et al. Atrial fibrillation following coronary artery bypass graft surgery: Predictors, outcomes, and resource utilization. MultiCenter study of perioperative ischemia research group. JAMA 1996;276:300-6.

34. Gaudino M, Andreotti F, Zamparelli R, Di Castelnuovo A, Nasso G, Burzotta F, et al. The -174G/C interleukin-6 polymorphism influences postoperative interleukin-6 levels and postoperative atrial fibrillation. is atrial fibrillation an inflammatory complication? Circulation 2003;108(Suppl 1):II195-9.

35. Banach M, Rysz J, DrozdzJA, Okonski P, Misztal M, Barylski M, et al. Risk factors of atrial fibrillation following coronary artery bypass grafting: A preliminary report. Circ J 2006;70:438-41.

36. Benjamin EJ, Levy D, Vaziri SM, D’Agostino RB, Belanger AJ, Wolf PA. Independent risk factors for atrial fibrillation in a population-based cohort. the framingham heart study. JAMA 1994;271:840-4.

37. Zacharias A, Schwann TA, Riordan CJ, Durham SJ, Shah AS, Habib RH. Obesity and risk of new-onset atrial fibrillation after cardiac surgery. Circulation 2005; 112:3247-55.

38. Echahidi N, Mohty D, Pibarot P, Despres JP, O'Hara G, Champagne J, et al. Obesity and metabolic syndrome are independent risk factors for atrial fibrillation after coronary artery bypass graft surgery. Circulation 2007;116 Suppl 11:1213-9.

39. Ata Y, Turk T, Ay D, Eris C, Demir M, Ari H, et al. Ability of B-type natriuretic peptide in predicting postoperative atrial fibrillation in patients undergoing coronary artery bypass grafting. Heart Surg Forum 2009;12:E211-6.

40. Mendes LA, Connelly GP, McKenney PA, Podrid PJ, Cupples LA, Shemin $\mathrm{RJ}$, et al. Right coronary artery stenosis: An independent predictor of atrial fibrillation after coronary artery bypass surgery. J Am Coll Cardiol 1995;25:198-202.

41. Shen J, Lall S, Zheng V, Buckley P, Damiano RJ Jr, Schuessler RB. The persistent problem of new-onset postoperative atrial fibrillation: $A$ single-institution experience over two decades. J Thorac Cardiovasc Surg 2011;141:559-70.

42. Manning WJ, Gelfand EV. Left atrial size and postoperative atrial fibrillation: The volume of evidence suggests it is time to break an old habit. J Am Coll Cardiol 2006;48:787-9.

43. Nattel $\mathrm{S}$. New ideas about atrial fibrillation 50 years on. Nature 2002;415:219-26.

44. Zaman AG, Archbold RA, Helft G, Paul EA, Curzen NP, Mills PG. Atrial fibrillation after coronary artery bypass surgery: A model for preoperative risk stratification. Circulation 2000;101:1403-8.

45. Steinberg JS, Zelenkofske S, Wong SC, Gelernt M, Sciacca R, Menchavez E. Value of the P-wave signal-averaged ECG for predicting atrial fibrillation after cardiac surgery. Circulation 1993;88:2618-22.

46. Buxton AE, Josephson ME. The role of $\mathrm{P}$ wave duration as a predictor of postoperative atrial arrhythmias. Chest 1981;80:68-73.

47. Koch CG, Li L, Van Wagoner DR, Duncan AI, Gillinov AM, Blackstone EH. Red cell transfusion is associated with an increased risk for postoperative atrial fibrillation. Ann Thorac Surg 2006;82:1747-56.

48. Hashimoto K, Ilstrup DM, Schaff HV. Influence of clinical and hemodynamic variables on risk of supraventricular tachycardia after coronary artery bypass. J Thorac Cardiovasc Surg 1991;101:56-65.

49. Leitch JW, Thomson D, Baird DK, Harris PJ. The importance of age as a predictor of atrial fibrillation and flutter after coronary artery bypass grafting. J Thorac Cardiovasc Surg 1990;100:338-42.

50. Salaria V, Mehta NJ, Abdul-Aziz S, Mohiuddin SM, Khan IA. Role of postoperative use of adrenergic drugs in occurrence of atrial fibrillation after cardiac surgery. Clin Cardiol 2005;28:131-5.

51. Wahr JA, Parks R, Boisvert D, Comunale M, Fabian J, Ramsay J, et al. Preoperative serum potassium levels and perioperative outcomes in cardiac surgery patients. multicenter study of perioperative ischemia research group. JAMA 1999;281:2203-10.

52. England MR, Gordon G, Salem M, Chernow B. Magnesium administration and dysrhythmias after cardiac surgery. A placebo-controlled, doubleblind, randomized trial. JAMA 1992;268:2395-402.

53. White CM, Caron MF, Kalus JS, Rose H, Song J, Reddy P, et al. Intravenous plus oral amiodarone, atrial septal pacing, or both strategies to prevent post-cardiothoracic surgery atrial fibrillation: The atrial fibrillation suppression trial II (AFIST II). Circulation 2003;108(Suppl 1):II200-6.

54. Giri S, White CM, Dunn AB, Felton K, Freeman-Bosco L, Reddy P, et al. Oral amiodarone for prevention of atrial fibrillation after open heart surgery, the atrial fibrillation suppression trial (AFIST): A randomised placebo-controlled trial. Lancet 2001;357:830-6.

55. Crystal E, Garfinkle MS, Connolly SS, Ginger TT, Sleik K, Yusuf SS. Interventions for preventing post-operative atrial fibrillation in patients undergoing heart surgery. Cochrane Database Syst Rev 2004;CD003611.

56. Andrews TC, Reimold SC, Berlin JA, Antman EM. Prevention of supraventricular arrhythmias after coronary artery bypass surgery. A meta-analysis of randomized control trials. Circulation 1991;84(5 Suppl):III236-44.

57. Burgess DC, Kilborn MJ, Keech AC. Interventions for prevention of post-operative atrial fibrillation and its complications after cardiac surgery: A meta-analysis. Eur Heart J 2006;27:2846-57.

58. Guarnieri T, Nolan S, Gottlieb SO, Dudek A, Lowry DR. Intravenous amiodarone for the prevention of atrial fibrillation after open heart surgery: The amiodarone reduction in coronary heart $(\mathrm{ARCH})$ trial. J 
Am Coll Cardiol 1999;34:343-7.

59. Crystal E, Connolly SJ, Sleik K, Ginger TJ, Yusuf S. Interventions on prevention of post-operative atrial fibrillation in patients undergoing heart surgery: A meta-analysis. Circulation 2002;106:75-80.

60. Daoud EG, Snow R, Hummel JD, Kalbfleisch SJ, Weiss R, Augostini $R$. Temporary atrial epicardial pacing as prophylaxis against atrial fibrillation after heart surgery: A meta-analysis. J Cardiovasc Electrophysiol 2003;14:127-32.

61. Fan K, Lee KL, Chiu CS, Lee JW, He GW, Cheung D, et al. Effects of biatrial pacing in prevention of postoperative atrial fibrillation after coronary artery bypass surgery. Circulation 2000;102:755-60.

62. Wijeysundera DN, Beattie WS, Rao V, Karski J. Calcium antagonists reduce cardiovascular complications after cardiac surgery: A metaanalysis. J Am Coll Cardiol 2003;41:1496-505.

63. Dobrilovic N, Vadlamani L, Buchert B, Wright CB. Diltiazem prophylaxis reduces incidence of atrial fibrillation after coronary artery bypass grafting. J Cardiovasc Surg (Torino) 2005;46:457-61.

64. Miller S, Crystal E, Garfinkle M, Lau C, Lashevsky I, Connolly SJ. Effects of magnesium on atrial fibrillation after cardiac surgery: A meta-analysis. Heart 2005;91:618-23.

65. Shiga T, Wajima Z, Inoue T, Ogawa R. Magnesium prophylaxis for arrhythmias after cardiac surgery: A meta-analysis of randomized controlled trials. Am J Med 2004;117:325-33.

66. Patti G, Chello M, Candura D, Pasceri V, D'Ambrosio A, Covino E, et al. Randomized trial of atorvastatin for reduction of postoperative atrial fibrillation in patients undergoing cardiac surgery: Results of the ARMYDA-3 (atorvastatin for reduction of MYocardial dysrhythmia after cardiac surgery) study. Circulation 2006;114:1455-61.

67. Calo L, Bianconi L, Colivicchi F, Lamberti F, Loricchio ML, de Ruvo E, et al. N-3 fatty acids for the prevention of atrial fibrillation after coronary artery bypass surgery: A randomized, controlled trial. J Am Coll Cardiol 2005; $45: 1723-8$.

68. Mozaffarian D, Psaty BM, Rimm EB, Lemaitre RN, Burke GL, Lyles MF, et al. Fish intake and risk of incident atrial fibrillation. Circulation 2004;110:368-73.

69. Cheruku KK, Ghani A, Ahmad F, Pappas P, Silverman PR, Zelinger A, et al. Efficacy of nonsteroidal anti-inflammatory medications for prevention of atrial fibrillation following coronary artery bypass graft surgery. Prev Cardiol 2004;7:13-8.

70. Halonen J, Halonen P, Jarvinen O, Taskinen P, Auvinen T, Tarkka M, et al. Corticosteroids for the prevention of atrial fibrillation after cardiac surgery: A randomized controlled trial. JAMA 2007;297:1562-7.
71. Echahidi N, Pibarot P, O’Hara G, Mathieu P. Mechanisms, prevention, and treatment of atrial fibrillation after cardiac surgery. J Am Coll Cardiol 2008;51:793-801.

72. Lee JK, Klein GJ, Krahn AD, Yee R, Zarnke K, Simpson C, et al. Rate-control versus conversion strategy in postoperative atrial fibrillation: Trial design and pilot study results. Card Electrophysiol Rev 2003;7:178-84.

73. Zarowitz B, Gheorghiade M. Optimal heart rate control for patients with chronic atrial fibrillation: are pharmacologic choices truly changing? Am Heart J. 1992;123:1401-1403.

74. Clemo HF, Wood MA, Gilligan DM, Ellenbogen KA. Intravenous amiodarone for acute heart rate control in the critically ill patient with atrial tachyarrhythmias. Am J Cardiol 1998;81:594-8.

75. Bucerius J, Gummert JF, Borger MA, Walther T, Doll N, Onnasch JF, et al. Stroke after cardiac surgery: A risk factor analysis of 16,184 consecutive adult patients. Ann Thorac Surg 2003;75:472-8.

76. Hogue CW Jr, Murphy SF, Schechtman KB, Davila-Roman VG. Risk factors for early or delayed stroke after cardiac surgery. Circulation 1999;100:642-7.

77. Meurin P, Weber H, Renaud N, Larrazet F, Tabet JY, Demolis P, et al. Evolution of the postoperative pericardial effusion after day 15: The problem of the late tamponade. Chest 2004;125:2182-7.

78. Epstein AE, Alexander JC, Gutterman DD, Maisel W, Wharton JM; American College of Chest Physicians. Anticoagulation: American college of chest physicians guidelines for the prevention and management of postoperative atrial fibrillation after cardiac surgery. Chest 2005;128(2 Suppl):24S-7S.

79. Segal JB, McNamara RL, Miller MR, Kim N, Goodman SN, Powe NR, et al. Prevention of thromboembolism in atrial fibrillation. A meta-analysis of trials of anticoagulants and antiplatelet drugs. J Gen Intern Med 2000;15:56-67.

80. Rader F, Costantini O, Jarrett C, Gorodeski EZ, Lauer MS, Blackstone EH. Quantitative electrocardiography for predicting postoperative atrial fibrillation after cardiac surgery. J Electrocardiol 2011;44:761-7.

81. Amar D, Shi W, Hogue CW Jr, Zhang H, Passman RS, Thomas B, et al. Clinical prediction rule for atrial fibrillation after coronary artery bypass grafting. J Am Coll Cardiol 2004;44:1248-53.

Cite this article as: Mostafa A, EL Haddad MA, Shenoy M, Tuliani T. Atrial fibrillation post cardiac bypass surgery. Avicenna J Med 2012;2:65-70.

Source of Support: Nil, Conflict of Interest: None declared.

\section{Author Help: Online submission of the manuscripts}

Articles can be submitted online from http://www.journalonweb.com. For online submission, the articles should be prepared in two files (first page file and article file). Images should be submitted separately.

1) First Page File:

Prepare the title page, covering letter, acknowledgement etc. using a word processor program. All information related to your identity should be included here. Use text/rtt/doc/pdf files. Do not zip the files.

2) Article File:

The main text of the article, beginning with the Abstract to References (including tables) should be in this file. Do not include any information (such as acknowledgement, your names in page headers etc.) in this file. Use text/rtf/doc/pdf files. Do not zip the files. Limit the file size to $1024 \mathrm{~kb}$. Do not incorporate images in the file. If file size is large, graphs can be submitted separately as images, without their being incorporated in the article file. This will reduce the size of the file.

3) Images:

Submit good quality color images. Each image should be less than $\mathbf{4 0 9 6} \mathbf{~ k b}$ (4 MB) in size. The size of the image can be reduced by decreasing the actual height and width of the images (keep up to about 6 inches and up to about $1800 \times 1200$ pixels). JPEG is the most suitable file format. The image quality should be good enough to judge the scientific value of the image. For the purpose of printing, always retain a good quality, high resolution image. This high resolution image should be sent to the editorial office at the time of sending a revised article.

4) Legends:

Legends for the figures/images should be included at the end of the article file. 